\title{
EDITORIAL
}

\section{Avaliação nas Escolas Médicas}

Ganhou as páginas dos jornais e as telas da televisão, com grande destaque, a polêmica sobre o exame que o Ministério da Educação (ME) programou para o início de novembro, com a finalidade de avaliar os cursos de Administração, Direito e Engenharia Civil. A divisão de opiniões atingiu todas as partes envolvidas, estudantes, professores e administradores e, dentres estes, curiosamente, os reitores das universidades públicas foram os que mais se opuseram à idéia. Os principais argumentos contrários baseiam-se na limitação do instrumento de avaliação (uma prova teórica) e no arranhamento da autonomia universitária, enquanto os favoráveis antevêem, no "provão", o início de uma era de controle de qualidade do processo de formação do profissional de nível universitário.

Ao fixar a obrigatoriedade de comparecimento ao exame, pré-requisito para registro do diploma, irrespectivamente da nota obtida, o ME objetivou, explicitamente, reproduzir o bem-sucedido processo de avaliação dos cursos de Pós-Graduação realizado bianualmente pela CAPES. Como, neste caso, o resultado da avaliação constitui critério para a distribuição de verbas e bolsas, é fácil de entender a resistência das instituições públicas ao exame. As privadas, que não dependem de financiamento do $\mathrm{ME}$ e, de modo geral, não têm bom conceito junto à sociedade, veriam, no exame, alguma chance de reverter este conceito. Mesmo que ele seja confirmado, não confiam em que o governo disponha de instrumentos jurídicos e cacife político para tomar qualquer providência com os cursos ineficientes, ainda mais com a excusa de que muitas provas foram anuladas voluntariamente pelos estudantes. Do lado destes, boa parte da resistência à avaliação terminal externa reside no temor de que ela, inicialmente designada para monitorar os cursos, transforme-se em uma barreira para o exercício profissional, como ocorre no Brasil com o exame da $O A B$ e, em outros países, de um modo mais amplo.

No próximo ano, esta discussão estará mais próxima de nós, pois o "provão” deverá ser estendido ao curso médico. Se, como argumentam os estudantes e os reitores, uma avaliação terminal externa é desnecessária, será que a sociedade está suficientemente protegida, quanto à qualidade profissional do formando, com a avaliação realizada dentro das universidades?

Em relação à Faculdade de Medicina de Ribeirão Preto, uma das mais conceituadas do país, a resposta é seguramente negativa. Em primeiro lugar, porque os requisitos mínimos de aprovação exigidos pela USP (média 5,0 e 70\% de frequência) são inadequados, pelo menos para o curso médico. Em correspondência enviada à Comissão de Graduação (CG) da FMRP para tratar do tema, em dezembro último, indaguei: “...seria prudente confiar uma vida humana a um médico que tivesse sistematicamente faltado em $30 \%$ das suas aulas e demonstrado apenas conhecer $50 \%$ do conteúdo, ter $50 \%$ de habilidades e $50 \%$ dos padrões éticos exigidos para a formação médica básica? Confiar-se-ia em um profissional que tivesse nota 9,0 na prova teórica e 1,0 na prova prática (ou vice-versa) de uma disciplina (média 5,0, aprovado)?...A presença de um sistema de avaliação de desempenho estudantil justo e eficiente constitui um requisito indispensável para a manutenção da qualidade de ensino, além de garantir a competência do profissional formado. Fugindo deste binômio (ensino eficiente e avaliação rigorosa), cai-se na triste realidade de alguns cursos, onde "finge-se que se ensina e que se avalia, todos são aprovados e vai se aprender mesmo na Residência Médica”. Infelizmente, uma considerável parcela do alunato, por imaturidade e interesses imediatistas, adere a este modelo, acomodando-se à pobreza dos cursos e encontrando eco, muitas vezes, em um corpo docente sobrecarregado por outras atividades universitárias mais valorizadas. A consequência deste sistema falho de controle de qualidade é, nas palavras de um colega, que 
o "indice de reprovação na FMRP, perto de zero, é muito inferior ao de muitas faculdades particulares da cidade", resultando em desestímulo aos docentes que se empenham em seus cursos e perda de respeito pelos mesmos por parte dos próprios alunos, que vêem a instituição incapaz de detectar a natureza gaussiana da composição do alunato e de intervir sobre a "cauda esquerda" desta distribuição". As poucas reprovações que existem não repercutem nos alunos, que repõem provas ou cursos concomitantemente com as novas disciplinas e a nota de reprovação nem aparece no histórico escolar!

Naquela correspondência, questionei a extinção dos regimes de dependência e de pré-requisitos, que tinha ocorrido na prática, e o excesso de oportunidades de aprovação oferecidas aos alunos (3 consecutivas) por orientação da CG. A maioria destas falhas foi sanada no ano de 1996 e espero que, no próximo, seja também corrigida uma outra, mais grave ainda, apontada em minha manifestação abaixo à CG: a ausência de um sistema de avaliação sério no internato médico.

"A explicação tradicional para ausência de avaliação no internato, de que não há conteúdo teórico nos cursos deste período, não convence. pois este conteúdo existe, sendo ministrado de uma forma menos sistemática do que no ciclo clínico e, o que é mais importante, o treinamento prático que constitui o cerne do programa de internato, pode perfeitamente ser avaliado, como tem sido feito, com muita eficiência, por iniciativa da própria CG/FMRP. Por que esta avaliação não é ou não se torna oficial? A nosso ver, a dificuldade de implementá-la reside no mesmo conluio corporativo, subjacente entre o professorado ("não me cobre bons cursos") e o alunato ("não me cobre desempenho"). A posição oficial dos alunos a respeito, expressa recentemente na Congregação, defende que a avaliação seja feita ao longo do internato, através da observação do trabalho clínico dos estudantes. Esta forma, altamente subjetiva e imperfeita, não difere da vigente e não dispensa outras mais padronizadas e discriminativas, principalmente uma avaliação terminal abrangente no final do curso.

Defendo, com tranquilidade, a reserva de vagas de residência médica para os formandos do respectivo curso médico, já que este, atualmente, não se completa em 6 anos, mas em 9 ou 10 e cada faculdade tem o compromisso de terminalidade com seus estudantes. Na prática, dada a frouxidão dos mecanismos avaliatórios da FMRP e a compulsoriedade do exame para ingresso na residência médica, apenas este último acaba detectando os alunos insuficientes, que, muitas vezes, nem deveriam ter se graduado. Muitos deles não conseguem vaga na residência médica da FMRP ou de outras instituições, onde poderiam recuperar sua formação básica, caindo no mercado de trabalho completamente despreparados e ameaçando a sociedade. Seria muito mais lógico usar ainda no curso médico o rigor e a abrangência da prova da residência médica, complementando a avaliação prática dos componentes afetivo e psicomotor da aprendizagem e constituindo um exame de competências terminais que garantiria um nível mínimo de qualidade do futuro profissional. Aos estudantes que atingissem este nível, seria oferecida, além do diploma legal, o treinamento prático da residência médica que os capacitaria, verdadeiramente, ao exercício da profissão. Aos que não o atingissem, seria proporcionada oportunidade de recuperação, dentro do próprio curso de graduação, sem precisar de exibir aos quatro ventos suas deficiências portando um diploma de médico emitido pela USP.

Em outro nível de avaliação, falta-nos, também, um sistema regular de monitoramento que permita detectar e corrigir precocemente distúrbios graves de personalidade que possam comprometer, no futuro, o desempenho profissional do egresso do curso médico.

Se não cuidarmos adequadamente de avaliar a qualidade do produto que formamos, a sociedade, seguramente, o fará por nós. Se o fizermos, não teremos receio de qualquer tipo de avaliação externa.

Prof. Dr. Júlio C. Voltarelli

Editor 